\title{
Leaders
}

\section{Viral gastroenteritis: small round structured viruses, caliciviruses and astroviruses. Part II. The epidemiological perspective}

\author{
E Owen Caul
}

\section{Introduction}

Part I of this review, published in the previous issue of this journal, presented the clinical and diagnostic perspective of these viruses. The epidemiology of each virus is now analysed in detail.

Small round structured viruses (SRSV) Following the original description of Norwalk virus in the USA, this group of viruses has become established as the most important cause of outbreaks of epidemic non-bacterial gastroenteritis worldwide. " In particular, the diversity of settings associated with these economically important viruses is amply demonstrated by the early American studies. Thus, Norwalk virus was responsible for a community-wide outbreak in Ohio, while the Hawaii and Montgomery County agents were associated with small family outbreaks. ${ }^{1}$ The Snow mountain agent caused an epidemic at a holiday camp in Colorado, "' while on this side of the Atlantic the Taunton agent was responsible for the considerable disruption which arose in an orthopaedic and geriatric ward in two hospitals in southern England. ${ }^{11}$ "12 In subsequent studies of non-bacterial gastroenteritis in many parts of the world the potential that SRSVs have for causing epidemic gastroenteritis in semi-closed or community-wide populations has been well documented. Outbreaks have been recorded in family settings, health care institutions, holiday and travel settings, cruise ships, homes for the elderly and in schools or colleges. ${ }^{1 * 0}$ The comprehensive sero-epidemiological studies carried out in the USA, ${ }^{1} 1311$ in conjunction with the direct detection of SRSVs by electron microscopy, particularly in the UK and Japan as well as elsewhere in the world, reinforces the importance of these viruses in community-wide outbreaks. Such outbreaks often have significant economic implications. The UK initiatives directed towards the surveillance and diagnosis by electron microscopy of outbreaks of nonbacterial gastroenteritis have recently shown that SRSVs are a more common cause of outbreaks than Salmonella. In addition, the UK data demonstrate an increasing prevalence of SRSVs in recent years (fig 1) with the

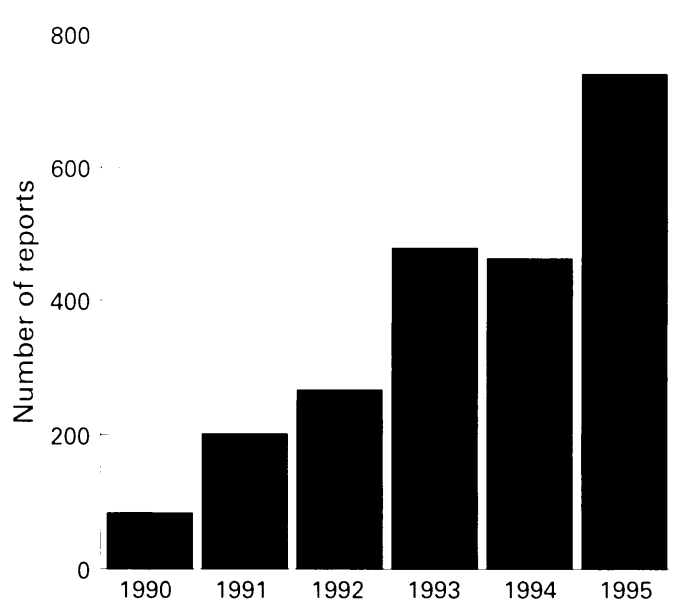

Figure 1 Anmal SRSL laboratory reports in England and Wales 1990-1995. Data for 1993-1995 are proitisional.

suggestion of a winter seasonality (fig 2) and also show that all age groups are affected (fig 3). Furthermore, epidemiological studies have shown that outbreaks of SRSVs commonly occur in children and adults but less often in neonates or very young children. All of these epidemiological observations contrast with those of the classic caliciviruses and astroviruses which are rarely implicated in outbreaks of gastroenteritis in adults.

It is now apparent that SRSVs commonly circulate in the community and are often spread from person to person. This observation in conjunction with the high infectivity of SRSVs (10-100 virus particles) gives rise to a significant potential for point source outbreaks and this is now recognised. In many explosive outbreaks a vehicle for transmission, other than the person to person route, has been identified. Thus contaminated water supplies in America in the form of municipal water, semi-public water, drinking water on cruise ships, recreational swimming water (pool or lake) as well as commercially produced ice-cubes have been incriminated in SRSV outbreaks. ${ }^{1401517}$ Additionally, food-borne outbreaks have also been well recognised where food specific attack rates have produced epidemiological evidence that has identified contaminated salads, bakery products, cold foods, sandwiches, cooked meat, and fresh fruit as vehicles for 


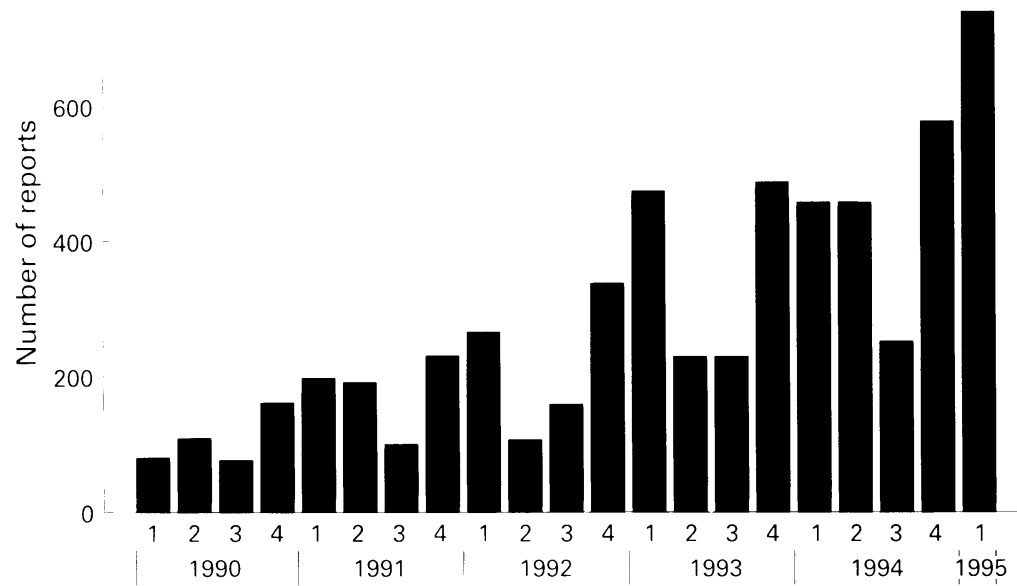

Figure 2 Seasonal distribution of SRSV's in England and Wales 1990-1995. Data for 1993-1995 ari prozisional.

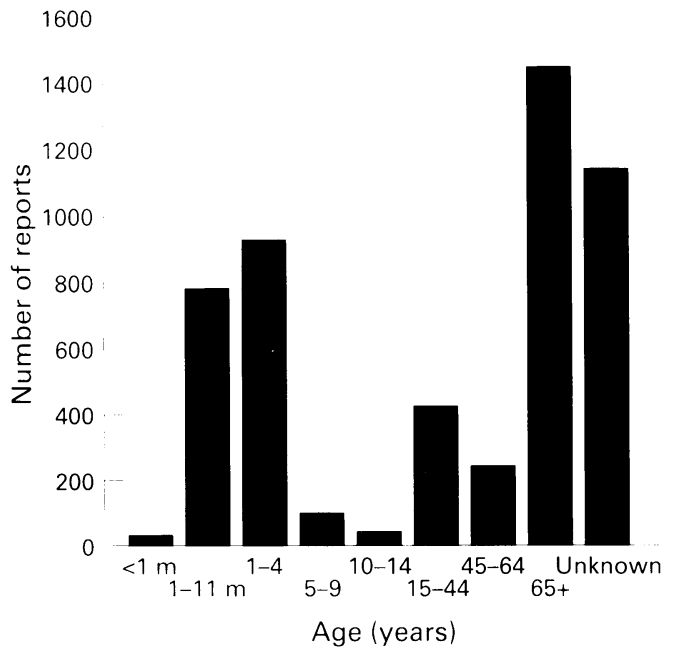

Figure 3 Age distribution of SRSV in England and Wales. Cumulatioe totals 1990-1995.

transmission. breaks the source of the contamination has implicated a symptomatic or recently symptomatic food handler. ${ }^{121 " 21}$ It is apparent that any food can transmit SRSV if it is handled after cooking or otherwise by an infected food handler. The important aspect of food-borne transmission is that the secondary attack rate is often high $(>50 \%)$ which in turn amplifies the initial point source outbreak.

A well established and major source of food borne gastroenteritis arises from the consumption of contaminated shellfish. ${ }^{7}$ is 22 The shellfish most commonly reported are the bivalve molluscs (oysters, cockles and mussels) which become infected from the raw sewage

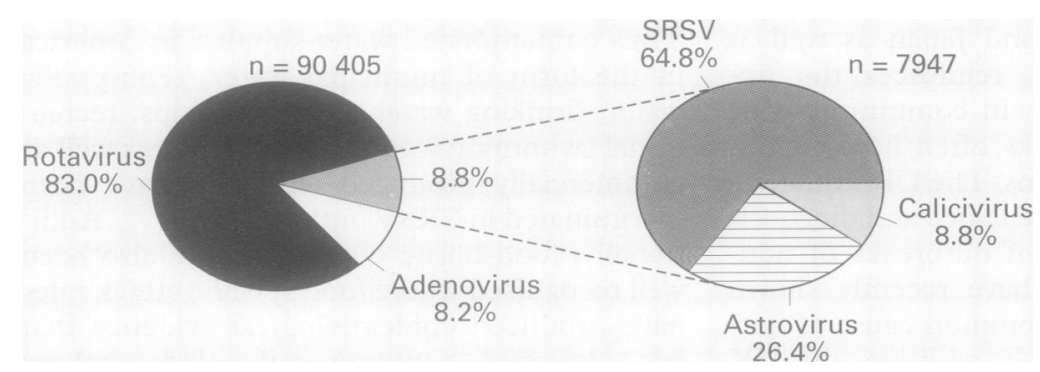

Figure 4 Relative percentages of enteric viruses in England and Wales. Cumulative totals $1990-1995$. that contaminates shellfish beds. SRSVs are an important cause of food borne non-bacterial gastroenteritis in the UK, arising from eating shellfish and are commonly under-reported. Small and large outbreaks have also been reported in the USA, Japan and Australia where in the latter case more than 2000 people were affected..$^{3}$ A recent study using the reverse transcription polymerase chain reaction (RT-PCR) and genome sequencing identified a symptomatic fisherman as the source of contamination of an oyster bed in the USA, arising from the fisherman defecating directly into the water adjacent to the oyster bed. ${ }^{25}$ The contamination of shellfish worldwide by sewage presents a major challenge to the food industry and others if reductions in transmission are to be achieved.

Initial studies in the UK suggested that $20-25 \%$ of known SRSV outbreaks were food associated, ${ }^{18}$ whilst $67 \%$ of 38 SRSV outbreaks in Japan were food related. ${ }^{20}$ In these studies shellfish were identified as a major source of the outbreaks. State-wide studies in America, using the Kaplan criteria for identifying SRSV outbreaks, implicated food-borne transmission in $39 \%$ of outbreaks.

\section{Classic caliciviruses}

The first definitive report of an association between a human enteric calicivirus and viral diarrhoea came from studies carried out in Glasgow. ${ }^{2 *}$ Investigations on the causes of gastroenteritis in children revealed the presence of classic caliciviruses in both symptomatic and asymptomatic children. Subsequently, most of our data on the epidemiology of caliciviruses were derived from electron microscopic observations and limited seroprevalence studies.

Studies of sporadic cases of childhood diarrhoea have documented excretion rates from $0.9 \%$ to $6.6 \%$ suggesting that, in common with astroviruses, they are a minor cause of clinically important disease. Subclinical infection in neonates is well documented which contrasts with the symptomatic infection recognised in older children. Analysis of the national surveillance data derived from electron microscopists in the UK between 1985 and 1987 showed that caliciviruses accounted for $0.9 \%$ of the total number of positive identifications of diarrhoea viruses reported." The majority of these calicivirus reports $(>90 \%)$ were documented in children under five years of age. Similar analysis of more recent national data in the UK (1990-1994) shows that caliciviruses accounted for $0.8 \%$ of all positive diarrhoea virus reports, which is remarkably similar to the previous report. Further analysis of small round diarrhoea viruses alone (SRSV, calicivirus and astrovirus) show that caliciviruses account for $8.8 \%$ of these reported viruses (fig 4 ). It is concluded that caliciviruses are a minor cause of clinically significant disease in the UK paediatric population and infected children are rarely admitted to hospital for medical intervention.

Although sporadic cases of human enteric caliciviruses infections are well documented, ${ }^{30}$ " community infections and hospital 


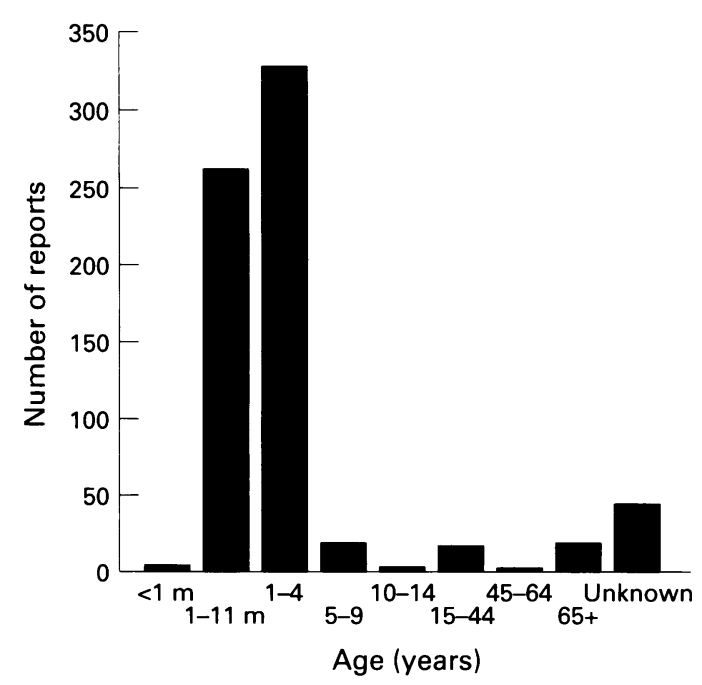

Figure 5 Age distribution of caliciviruses in England and Wales. Cumulative totals 1990-1995.

outbreaks have also been recognised occasionally. The first community outbreak to be reported was in an infant and junior school in North London. ${ }^{35}$ Caliciviruses were conclusively shown to be the causative agent and the outbreak resembled winter vomiting disease, although spread to other children in the other classes in the school and to secondary home contacts was negligible. These epidemiological observations contrast with the high secondary attack rate documented for classic winter vomiting disease caused by SRSVs. Outbreaks have been documented subsequently in Japan, Australia, England, Canada, and Scandinavia. ${ }^{36-44}$ Some of these outbreaks occurred not only in children but also amongst elderly patients in nursing homes, ${ }^{38}{ }^{39}{ }^{42}$ where the attack rate in some outbreaks ranged from 50 to $70 \%$. Although outbreaks in the elderly have been reported, they are unusual and may occur because of a waning immunity, as documented for rotaviruses and respiratory syncytial virus. It is apparent from the British studies that caliciviruses are primarily a paediatric infection and are endemic in the community (fig 5). The reported number of cases is too small to draw any definitive conclusions on seasonality (fig 6 ). Further evidence that caliciviruses are primarily a paediatric infection is demonstrated by seroprevalence studies ${ }^{30} 3245-48$ showing that $90 \%$ of children and adults have acquired specific antibody and this high seroprevalence probably explains why so few outbreaks are recognised in adults. Convincing evidence that caliciviruses can be spread by the food-borne route is not yet available, although such occurrences should occur particularly through the consumption of contaminated shell-fish. The lack of documented evidence of shell-fish associated gastroenteritis caused by caliciviruses provides further evidence for the hypothesis that infection in childhood gives rise to life-long immunity.

\section{Astroviruses}

In common with other diarrhoea viruses most of our current knowledge on the epidemiology of astroviruses is based on their detection by electron microscopy. Limited seroprevalence studies complement these data and indicate that this group of viruses are primarily causal in paediatric diarrhoea, analogous to that documented for caliciviruses. Astroviruses have been reported from all five continents ${ }^{49}$ where a significant association with childhood diarrhoea has been noted. $.^{2-5} 4050-55$

Early studies in Glasgow documented that $80 \%$ of babies excreting the virus were symptomatic but a significant number of children $(12 \%)$ had no clinical evidence of gastroenteritis. ${ }^{8}{ }^{9} \mathrm{With}$ the recognition of astroviruses by electron microscopy came many reports documenting nosocomial spread, and outbreaks in infants and young children have been described in nurseries and paediatric wards. $^{4050-535657}$ A particularly large outbreak in children has been documented in Japan, where more than $50 \%$ of the children were symptomatic. ${ }^{51}$ In an outbreak in a children's ward in the UK nursing staff became infected and symptomatic, indicating that susceptibility into adult life does occur. ${ }^{57}$ Asymptomatic excretion of astroviruses has been variously reported from $5 \%$ to $20 \%$ in neonates and young children and this represents a significant source of spread in semi-closed communities such as hospitals or nurseries.

Comprehensive longitudinal studies on astrovirus prevalence in the community have been reported rarely. Initial electron microscopic analysis of the UK national surveillance data between 1985 and 1987 showed that astroviruses were endemic within the community with distinct peaks in the winter. ${ }^{29}$ In these studies a striking age related prevalence was noted. It was also clear that the majority of these symptomatic infections occurred in children under the age of five years. Other longitudinal studies in London reported that $2.8 \%$ of symptomatic children under the age of six excreted astroviruses but none of the children in the study between the ages of six and 12 years excreted virus. ${ }^{52}$ Analysis of more recent UK data shows that astroviruses account for $1-2 \%$ of all positive reports of diarrhoea viruses and if only the small round diarrhoea viruses are considered then they account for $26.4 \%$ (fig 4). This national data confirms that astroviruses are, like caliciviruses, only a minor cause of viral gastroenteritis in the UK and emphasise the age related (fig 7) and seasonal distribution (fig 8).

Although most astrovirus infections occur in paediatric populations, sporadic cases and outbreaks have been reported occasionally in adults. ${ }^{39}$ t0 555859 An outbreak occurred in a home for the elderly in Marin County California, where $51 \%$ of the residents developed gastroenteritis. ${ }^{59}$ Also an unusually large outbreak has been reported by Japanese workers which affected both students and teachers. ${ }^{58}$ Sporadic cases in adults have also been recognised but these make only a small contribution to the overall prevalence, at least in the UK. This is further substantiated by limited human volunteer studies in adults where symptomatic infection was uncommon and pre-existing astrovirus antibodies seemed to be protective. ${ }^{60}$ 
70

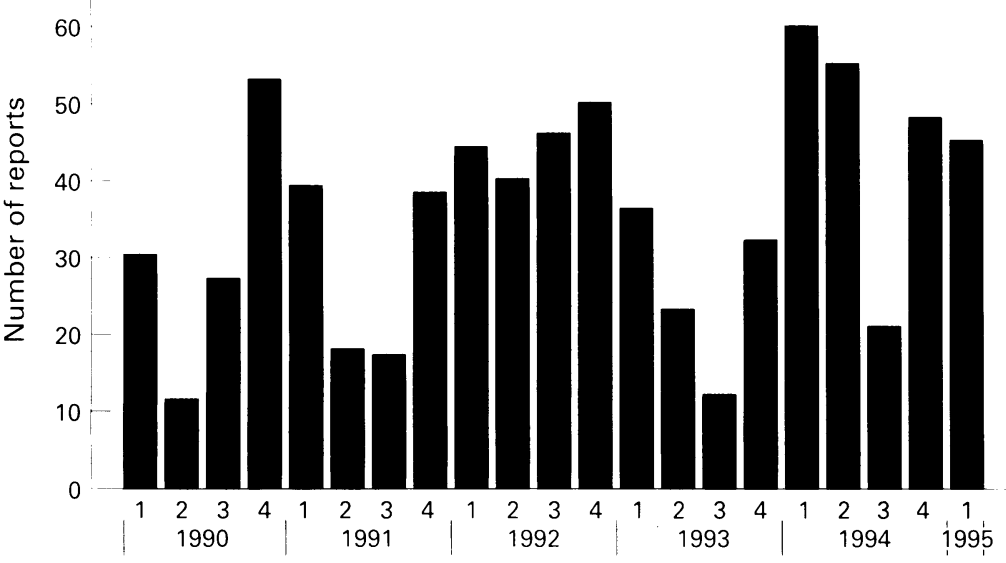

Figure 6 Seasonal distribution of caliciviruses in England and Wales 1990-1995. Data for 1993-1995 are provisional.

$$
1200
$$

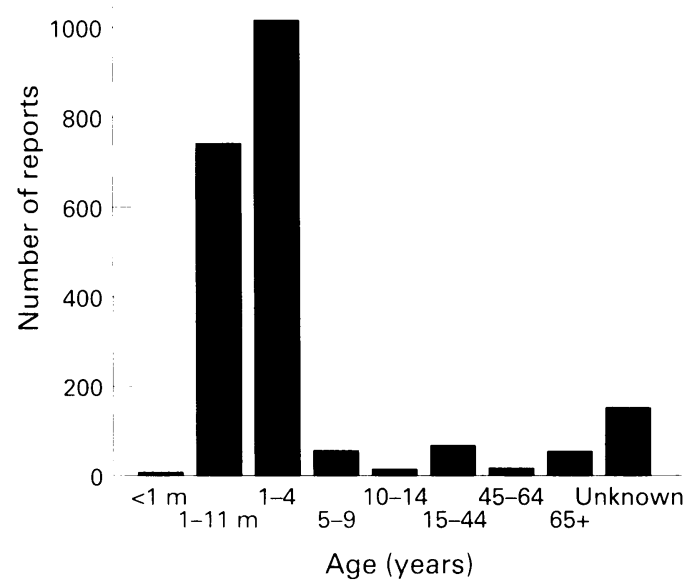

Figure 7 Age distribution of astroviruses in England and Wales. Cumulative totals 19901995.

This suggests that paediatric astrovirus infection, like calicivirus, gives rise to life-long immunity.

Astroviruses have rarely been incriminated in food- or water-borne outbreaks of gastroenteritis. However, in one oyster associated outbreak, involving naval officers, illness was documented within 24 hours of consuming the oysters and a second attack of gastroenteritis

300

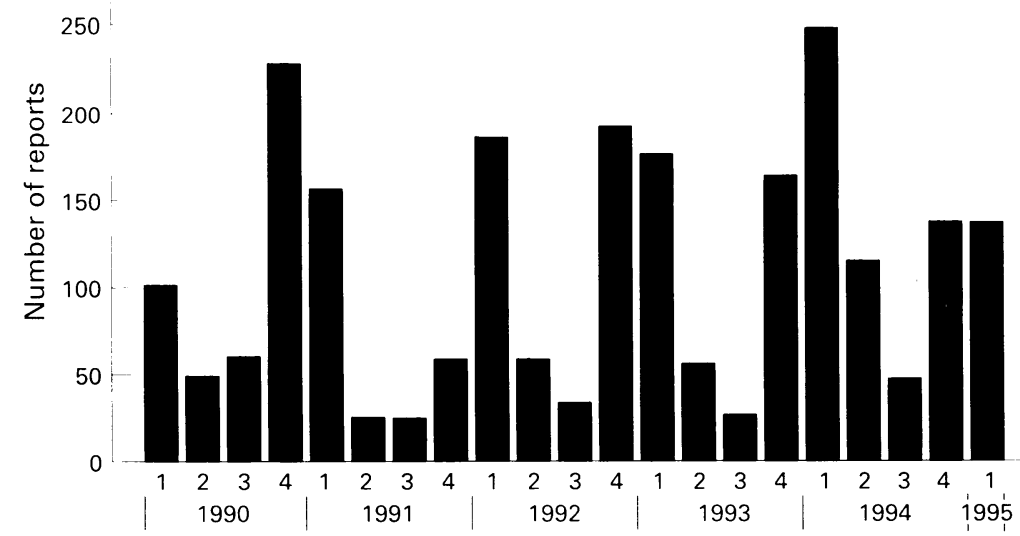

Figure 8 Seasonal distribution of astroviruses in England and Wales 1990-1995. Data for 1993-1995 are provisional. occurred four days later. SRSVs were identified as the cause of the first episode of gastroenteritis, while astroviruses were detected in stool samples collected at the time of the second episode. The identification of SRSVs and astroviruses is compatible with the known incubation periods of these two distinct families of viruses. ${ }^{2}(0)$ of

Seroprevalence studies have shown that $64 \%$ of three to four year olds have acquired specific astrovirus antibody and this rises to $87 \%$ in five to 10 year olds. ${ }^{.2}$ The sero-epidemiology of astroviruses complements our data on the prevalence of astroviruses detected by electron microscopy and confirms that infection occurs in early childhood. The high level of antibody acquisition in conjunction with the relatively small number of cases reported suggest that a significant number of infections are either subclinical or so mild that medical intervention is not sought by parents. This is analogous to the situation observed with calicivirus infections and contrasts sharply with the epidemiology and explosive outbreaks that commonly occur with SRSV infections in children and adults.

\section{Antigenic variations}

Antigenic variation amongst SRSVs has been reported by immune electron microscopy (IEM) using human convalescent serum to complex intact virions through capsid epitope reactivity. To date, four SRSV antigenic types have been identified in the $\mathrm{UK}^{13^{\prime \prime 5}}$ and six in the USA. ${ }^{\circ 6}$ Serotyping with human serum has been useful but there are still important interpretative difficulties. Similar investigations by Japanese workers ${ }^{2}$ have identified nine serotypes, ${ }^{20}$ although this may be an overestimate because of cross reactions within serotypes. The available information on antigenic variation amongst SRSVs is hampered by the use of human reagents and definitive data will depend on the production of specific hyperimmune serum or monoclonal antibodies. This is now feasible as a result of the molecular characterisation of SRSVs and the production of recombinant viral capsids in appropriate expression systems. ${ }^{67}$

Similar problems in identifying antigenic variation amongst classic caliciviruses are also recognised. To date, caliciviruses with a classic morphology have been grouped into four distinct antigenic types by IEM and a common antigenic epitope detectable by radioimmunoassay has been reported. ${ }^{+}$

In contrast with the above, the ability to propagate astroviruses in cell culture and the production of hyperimmune antisera and monoclonal antibodies have permitted the definitive identification of seven antigenic types by IEM and immunofluorescence. 2 i2 The recent development of a monoclonal antibody based enzyme immunoassay by Herrmann et $a i^{3}$ has confirmed the previously reported antigenic variation amongst astroviruses.

\section{Conclusions}

The routine surveillance of non-bacterial gastroenteritis in the UK by electron micros- 
copy has produced comprehensive data. It is now apparent that SRSVs are a major cause of epidemic diarrhoea and impact on food-borne gastroenteritis, particularly shell-fish associated incidents. Clear differences have emerged on the age related prevalence of SRSVs in comparison with all the other diarrhoea viruses - the latter being associated predominately with paediatric infections whilst SRSVs affect all age groups. It is clear that SRSVs are currently under diagnosed and new technologies using molecular approaches are necessary not only to ease and improve the diagnostic burden carried by electron microscopy units, but also to increase our knowledge of the epidemiology of this clinically important group of viruses. The recent advances in the molecular characterisation of all the small round viruses will allow us to achieve these aims.

My grateful thanks to the Communicable Disease Surveillance Centre (CDSC), Colindale, London, for allowing me to acces the raw epidemiological data used in the compilation of the figures.

1 Kapikian AZ (ed). Norwalk and Norwalk-like viruses. In Viral infections of the gastrointestinal tract. New York: Marce Dekker, 1994:471-518.

2 Caul EO. Small round human fecal viruses. In: Pattison JR, ed. Parvoviruses and human disease. Boca Raton, Florida CRC Press, 1988:139-63.

3 Cukor G, Blacklow NR. Human viral gastroenteritis. Microbiol Rev 1984;48:157-79.

4 Christensen ML. Human viral gastroenteritis. Clin Microbio Rev 1989;2:51-89.

5 Blacklow NR, Greenberg. Medical progress - viral gastroenteritis. N Engl f Med 1991;325:252-64.

6 Blacklow NR, Herrmann JE. Norwalk virus. Proceedings of the Ninth BSG SK\&F International Workshop, 1988:65-9.

7 Caul EO, Sellwood NJ, Brown DW, et al. Outbreaks of gastroenteritis associated with SRSVs. PHLS Microbiology Digest 1993;10:2-8.

8 Greenberg HB, Valdesuso J, Yolken RH, et al. Role of Norwalk virus in outbreaks of nonbacterial gastroenteritis. $\mathcal{F}$ walk virus in outbreaks of
Infect Dis 1979;130:564-8.

9 Kaplan JE, Gary GW, Baron RC, Singh N, Schonberger LB Feldman R, Greenberg HB. Epidemiology of Norwalk gastroenteritis. Ann Intern Med 1982;96:756-61.

10 Dolin R, Reichmann RC, Roessner KD, Tralka TS, Schooley RT, Gary W, et al. Detection by immune electron microscopy of the Snow Mountain agent of acute viral gastroenteritis. F Infect Dis 1982;146: 184-9.

11 Caul EO, Ashley CR, Pether JVS. "Norwalk"-like particles in epidemic gastroenteritis in the U.K. Lancet 1979;ii: 1292.

12 Pether JVS, Caul EO. An outbreak of foodborne gastroenteritis in 2 hospitals associated with a Norwalk-like virus. $\mathscr{f}$ Hyg 1983;91:343-50.

13 Kapikian AZ, Greenberg HB, Cline WL, et al. Prevalence of antibody to the Norwalk agent by a newly developed immune adherence hemagglutination assay. $\mathcal{f}$ Med Virol 1978;2:281-94.

14 Wyatt RG, Dolin R, Blacklow NR, et al. Comparison of three agents of acute infectious nonbacterial gastroenteritis by cross-challenge in volunteers. F Infect Dis 1974;129:70914.

15 Ho M, Glass RI, Monroe SS, et al. Viral gastroenteritis aboard a cruise ship. Lancet 1989; ii:961-4

16 Morens DM, Zweighaft RM, Vernon TM, et al. A waterborne outbreak of gastroenteritis with secondary person-to-person spread. Lancet 1979;i:964-6.

17 Wilson R, Anderson LJ, Holman RC, Gary GW, Greenber HB. Waterborne gastroenteritis due to the Norwalk agent-clinical and epidemiologic investigation. Am $\mathcal{F}$ Public Health 1982;72:72-4.

18 Caul EO. Viruses in food. In: Spencer RC, Wright EP, Newsom SWB, eds. Rapid methods and automation in microbiology and immunology. Andover, Hampshire: Intercept Ltd, ogy and immunot.

19 Griffin MR, Surowiec JJ, McCloskey, et al. Foodborne Norwalk virus. Am $\mathcal{F}$ Epidemiol 1982;115:178-84

20 Kuritsky JN, Osterholm MT, Korlath JA, White KE, Kaplan JE. A statewide assessment of the role of Norwalk virus in outbreaks of food-borne gastroenteritis. F Infect Dis 1985;151:568.

21 Reid JA, White DG, Caul EO, Palmer SR. Role of infected food handler in hotel outbreak of Norwalk-like vira gastroenteritis: implications for control. Lancet 1988;ii 321-3.

22 Morse DL, Guzewich JJ, Hanrahan JP, et al. Widespread outbreaks of clam- and oyster-associated gastroenteritis: role of Norwalk virus. $N$ Engl f Med 1986;314:678-81.
23 Murphy AM, Grohmann GS, Christopher PJ, Lopez WA, Davey GR, Millsom RH. An Australian-wide outbreak of gastroenteritis from oysters caused by Norwalk virus. Med f Aust 1979;2:329-33.

24 Murphy AM, Grohmann GS, Christopher PJ, Lopez WA Davey GR, Millsom RH. Norwalk-virus gastroenteritis following raw oyster consumption. Am $\mathcal{F}$ Epidemiol 1982;115: 348-51.

25 Dowell SF, Groves C, et al. A multistate outbreak of oysterassociated gastroenteritis: Implications for interstate tracing of contaminated shellfish. F Infect Dis 1995;171:1497503

26 Okada SS, Sekine S, Ando T, et al. Antigenic characterization of small, round-structured viruses by immune electron-microscopy. $\mathcal{F}$ Clin Microbiol 1990;28:1244-8.

27 Hedberg CW, Osterholm MT. Outbreaks of food-borne and waterborne viral gastroenteritis. Clin Microbiol Rev 1993;6: 199-210.

28 Madeley CR, Cosgrove BP. Caliciviruses in man. Lancet 1976;i:199-200.

29 Monroe SS, Glass RI, Noah N, et al. Electron microscopic reporting of gastrointestinal viruses in the United Kingdom 1985-1987. F Med Virol 1991;33:193-8.

30 Cubitt WD. The candidate caliciviruses. Ciba Foundation Symposia 1987;128:126-43.

31 Cubitt WD. Caliciviruses. Proceedings of the Ninth BSG SK\&F International Workshop, 1987:82-4

32 Cubitt WD. Caliciviruses. In: Kapikian AZ, ed. Viral infections of the gastrointestinal tract. New York: Marcel Dekker, 1994:549-68.

33 Cubitt WD, McSwiggan DA. Calicivirus gastroenteritis in North West London. Lancet 1981;ii:975-7.

34 Kjeldsberg E. Small spherical viruses in faeces from gastroenteritis patients. Acta Pathol Microbiol Scand 1977;85:351-4.

35 Cubitt WD, McSwiggan DA, Moore W. Winter vomiting disease caused by calicivirus. F Clin Pathol 1979;32:786-

36 Cubitt WD, McSwiggan DA, Arstali S. An outbreak of calicivirus infection in a mother and baby unit. $\mathcal{f}$ Clin Pathol 1980;33:1095-8.

37 Chiba S, Sakuma Y, Kogasaka R, Akihara M, Horino K, Nakao T, Fukui. An outbreak of gastroenteritis associated with calicivirus in an infant home. F Med Virol 1979;4:24954.

38 Cubitt WD, Pead PJ, Saeed AA. A new serotype of calicivirus associated with an outbreak of gastroenteritis in a resirus associated with an outbreak of gastroenteritis in a resi-

39 Gray JJ, Wreghitt TG, Cubitt WD, Elliot PR. An outbreak of gastroenteritis in a home for the elderly associated with astrovirus type-1 and human calicivirus. $\mathcal{F}$ Med Virol 1987; 23:377-81.

40 Greenberg HB, Matsui. Astroviruses and caliciviruses: emerging enteric pathogens. Agents Dis 1992;1:71-91.

41 Grohmann G, Glass RI, Gold M, et al. Outbreak of human $\mathbb{D}$ calicivirus gastroenteritis in a day-care center in Sydney, Australia. F Clin Microbiol 1991;29:544-50.

42 Humphrey TJ, Cruickshank JG, Cubitt WD. An outbreak of calicivirus associated gastroenteritis in an elderly persons home-a possible zoonosis. F Hyg 1984;93:293-9.

43 Matson DO, Estes MK, Glass RI, et al. Human calicivirusassociated diarrhea in children attending day care centers. $\mathcal{F}$ Infect Dis 1989;159:71-8.

44 Oishi I, Maeda A, Yamazaki K, Minekawa Y, Nishimura $H$, Kitaura T. Calicivirus detected in outbreaks of acute gastroenteritis in school-children. Biken $\mathcal{f} 1980 ; 23: 163-8$.

45 Cubitt WD, Blacklow NR, Herrmann JE, Nowak NA, Nakata S, Chiba S. Antigenic relationships between human caliciviruses and Norwalk virus. F Infect Dis 1987;156:806 14.

46 Nakata S, Chiba H, Terashima T, Yokoyama T, Nakao T Humoral immunity in infants with gastroenteritis caused by human calicivirus. F Infect Dis 1985;152:274-9.

47 Sakuma Y, Chiba S, Kogasaka R, Terashima H, Nakamura $S$, Horino K Nakao T. Prevalence of antibody to human calicivirus in general-population of northern Japan. $\mathcal{f} \mathrm{Med}$ Virol 1981;7:221-5.

48 Kurtz JB. Astroviruses. Proceedings of the 9th BSG SK \& F N Workshop, 1988:84-7.

49 Herrmann JE, Taylor DN, Echeverriae P, Blacklow NR Astroviruses as a cause of gastroenteritis in children. NEngl 0 fMed 1991;324:1757-60.

50 Konno T, Suzuki H, Ishida N, Chiba R, Mochizuki K, Tsu- $\mathbb{E}$ noda A. Astroviruses-associated epidemic gastroenteritis in ? Japan. $\mathcal{F}$ Med Virol 1982;9:11-17.

51 Kurtz JB. Astroviruses. In: Kapikian AZ, ed. Viral Infections of the gastrointestinal tract. New York: Marcel Dekker, 1994: 569-80.

52 Kurtz JB, LeE TW. Astroviruses: human and animal. Ciba $\mathbb{D}$ Foundation Symposia 1987;128:92-107.

53 Nazer H, Rice S, Walker-Smith JA. Clinical associations of stool astrovirus in childhood. $\mathcal{F}$ Pediatr Gastroenterol Nutr 1982;1:555-8.

54 Willcocks MM, Carter MJ, Madeley CR Astroviruses. Rev Med Virol 1992;2:97-106.

55 Ashley CR, Caul EO, Paver WK. Astrovirus-associated gas- 쁠 troenteritis in children. $\mathcal{F}$ Clin Pathol 1978;31:939-43.

56 Kurtz JB, Lee TW, Pickering D. Astrovirus associated gastroenteritis in a children's ward. $\mathcal{F}$ Clin Pathol 1977;30: 948-52.

57 Oishi I, Yamazaki K, Kimoto T, et al. A large outbreak acute gastroenteritis associated with astrovirus among students and teachers in Osaka, Japan. $\mathcal{F}$ Infect Dis 1994;170:43943. 
58 Oshiro LS, Haley CE, Roberto RR, Riggs JL, Croughan M, Greenberg $\mathrm{H}$, et al. A $27 \mathrm{~nm}$ virus isolated during an outbreak of acute infectious nonbacterial gastroenteritis in a convalescent home: a possible new serotype. F Infect Dis 1981;143:791-5.

59 Kurtz JB, Lee TW, Craig JW, Reed SE. Astrovirus infection in volunteers. f Med Virol 1979;3:221-30.

60 Dolin R. Norwalk and related agents of gastroenteritis. In: Mandell GL, Douglas RG, Bennett JE, eds. Principles and practice of infectious diseases. Edinburgh: Churchill Livingpractice of infectious dis
stone, 1979:1364-70.

61 Kurtz JB, Lee TW. Astrovirus gastroenteritis: age distribution of antibody. Med Microbiol 1978;166:227-30

62 Lambden PR, Caul EO, Ashley CR, Clarke IN. Sequence and genome organisation of a human small roundstructured (Norwalk-like) virus. Science 1993;259:516-9.

63 Lewis DC. Three serotypes of Norwalk-like virus demonstrated by solid-phase immune electron microscopy. $7 \mathrm{Med}$ Virol 1990;3:77-81.

64 Lewis D. Norwalk agent and other small-round structured viruses in the UK. F Infect 1991;23:220-2.

65 Lewis D, Ando T, Humphrey CD, Monroe SS, Glass RI. Lewis D, Ando T, Humphrey CD, Monroe SS, Glass RI.
Use of solid-phase immune electron-microscopy for classification of Norwalk-like viruses into 6 antigenic groups from 10 outbreaks of gastroenteritis in the United States. $\mathcal{F}$ Clin Microbiol 1995;33:501-4

66 Dingle KE, Lambden PR, Caul EO, Clarke IN. Human enteric Caliciviridae: the complete genome sequence and expression of virus-like particles from a genetic group II small round structured virus. F Gen Virol 1995;76:234955.

67 Graham DY, Jiang X, Tanaka T, Opekun AR, Madore HP, Estes MK. Norwalk virus infection of volunteers: new insights based on improved assays. F Infect Dis 1994;170: 34-43.

68 Jiang X, Matson DO, Ruiz-Palacios GM, Ju J, Treanon J, Pickering LK. Expression, self-assembly, and antigenicity of a Snow Mountain Agent-like calicivirus capsid protein. $\mathcal{f}$ Clin Microbiol 1995;33:1452-5.

69 Jiang X, Wang M, Graham DY, Estes MK. Expression, selfassembly, and antigenicity of the Norwalk virus capsid protein. $\mathcal{F}$ Virol 1992;66:6527-32.

70 Lew JF, Kapikian AZ, Jiang X, Estes MK, Green KY. Molecular characterization and expression of the capsid protein of a Norwalk-like virus recovered from a Desert protein of a Norwalk-like virus recovered from a Desert
Shield troop with gastroenteritis. Virology 1994;200:31925.

71 Lee TW, Kurtz JB. Prevalence of human astrovirus serotypes in the Oxford region 1976-92, with evidence for 2 new serotypes. Epidemiol Infect 1994;112:187-93.

72 Herrmann JE, Hudson RW, Perron-Henry DM, Kurtz JB, Blacklow NT. Antigenic characterization of cell-cultivated astrovirus serotypes and development of astrovirus-specific monoclonal antibodies. F Infect Dis 1988;158:182-5. 